This is an unpublished draft, to cite the full article, use

Moulin, Daniel (2015) 'Doubts about Religious Education in public schooling' International Journal of Christianity \& Education 19: 135-148, first published on May 15, 2015 DOI: $10.1177 / 2056997115583583$

Link to this article: http://ice.sagepub.com/content/19/2/135.full.pdf+html

\title{
Doubts about Religious Education in public Schooling
}

Daniel Moulin

Institute for Culture and Society, University of Navarra, Edificio Biblioteca Humanidades, 31009 Pamplona, Spain. Email: dmoulin@unav.es

\begin{abstract}
This article considers potential problems concerning Religious Education in public (statefunded) secondary schools in England in order to inform ongoing debates about religion in public education in the United States and elsewhere. Findings of empirical studies conducted in England are discussed in relation to arguments that critique Religious Education. It is argued that Religious Education as it is currently conceived and practised in England may be problematic for religious believers because it can misrepresent and critique religions, particularly Christianity. It is also suggested that the subject may be confused in its aims and purpose because it is not based upon any theological or religious authority. It is suggested that these problems may present challenges to religious identity formation among adolescents and therefore may be a cause of concern for religious communities.
\end{abstract}

\section{Keywords}

Christianity, identity formation, public schooling, religion, religious literacy,

Secularization

\section{Introduction}

More than 50 years have passed since Garforth (1961) published the article, 'Doubts about secondary school Scripture' and coined the term 'Cinderella subject', which has been used subsequently to refer to the subject's perceived low status among educators and school administrators (Copley, 2008). Since Garforth's time, Religious Education in state-funded schools in England has adapted to further changes in English society, from a subject originally intended as nondenominational Christian education, to its present crisis identified by some as the result of a lack of coherent aims, meaning and purpose (Chater and Erricker, 2013; Conroy et al., 2013).

Arguably, in the past 15 years more thorough empirical research has been undertaken in the field of Religious Education than in any other time in its history (Conroy et al., 2013; Jackson, 2007, 2011). Studies suggest that the subject faces difficulties similar to those identified by Garforth: poor practice, including oversimplified, low-level classroom activities; poor resourcing, particularly the lack of 
suitably qualified expert teachers; and the poor articulation, conceptualization and understanding of its educational goals and aims (Conroy et al., 2013;Copley, 2005; Ofsted, 2007). However, educators on both sides of the Atlantic insist that Religious Education for religious literacy along the lines of the current English model is educationally and conceptually coherent, beneficial for society, and should therefore not only continue in England but should also be practised elsewhere (e.g. Groome, 2013; Jackson, 2014; Keast, 2007; Moore, 2007; Wright, 2007).

Religious Education has been criticized on account of its suitably for secularized society on one hand (White, 2004), and the secularization of its subject matter on the other (Thompson, 2004a, 2004b). In this article, I add new insights to this ongoing debate about the subject by considering its potential impact upon religious believers and identity formation processes more broadly, and by questioning its coherence given the lack of religious authority underwriting its theological positioning. These issues were briefly considered by Garforth and are likely to be of importance to debates over religion in public education in other national contexts, but have been largely ignored by contemporary religious educators in England and elsewhere who have not focused on investigating the impact Religious Education may have upon religious identity formation. This oversight has been identified by those researchers who have sought to research processes of identity formation and their relation to Religious Education (Streib, 2001; Thanissaro, 2012; VisserVogel et al., 2012).

This article was prompted by discussions with religious educators in the United States who argued for an English-style Religious Education in North American classrooms at the Religious Education Association Annual Conference held in Boston in 2013 (Groome, 2013). I write from the perspective of a Christian educator with professional and research experience in England and continental Europe of Religious Education in public education. I believe a consideration of my arguments will be of benefit to readers in the United States and elsewhere who may favour the maintenance and introduction of a similar programme in their national contexts. My aim is to reconsider Garforth's observations with a particular consideration of the potential impact Religious Education may have on those students who may identify with, practice, or believe in, a religion. I draw upon recent empirical research, including interview studies I conducted while a postgraduate student at the University of Oxford exploring the reported schooling experiences of adolescent Christians, Jews and Muslims (Moulin, 2011, 2014, 2015, forthcoming).

By Religious Education (capitalized) I mean the curriculum subject set out by legislation in England and practised in English public schools (albeit in different forms) over the past 60 years. (I use 'public school' in its North American sense and not to refer to elite private institutions in England that are often affiliated to the Established Church.) Developments in Religious Education in this period have been reflected in the changing expressions used to describe it: Scripture; Religious Instruction; Religious Knowledge and Religious Education (Copley, 2008). Today in the contemporary upper secondary school, Religious Education is also often delivered through examination courses entitled Religious Studies or Philosophy and Ethics, and some secondary schools have therefore rebranded Religious Education as Philosophy and Religion, despite there being differences in approach to religions in these disciplines. These changes do not relate to religious education (un-capitalized) in a more general sense that may be practised in all kinds of contexts outside of public schools such as catechesis within churches. However, they do relate to Religious Education as practised in Church schools of a religious character in England, 
where similar issues have been identified to those of Religious Education in schools not of a religious character (Archbishops' Council Education Division, 2014).

\section{The instrumental turns from nondenominational religious instruction to non- confessional religious education}

When universal education was introduced in England with Forster's 1870 Education Act, the Government did so by supporting the already existent provision of the churches. It was decided that a focus on the Bible, something common to all Christians, could be free of denominational bias and fulfil the requirements of the churches and state (Cruikshank, 1964). Thus Religious Education, or 'Scripture', as it was then called, began as a stateendorsed supplement to denominational instruction provided within churches. With the introduction of compulsory secondary education after the Second World War, Religious Education became a statutory requirement (1944 Education Act) in English statemaintained schools for all pupils, which it remains today. Seventeen years later, Garforth (1961) expressed his concerns. These included poor teaching by reluctant non-specialists, teacher bias and ignorance, lack of interest among head teachers, and unstimulating lessons which over-simplified religion. Garforth, did not, however, critique the project of Religious Education as nondenominational Christian nurture for a Christian society as English religious educators have done more recently (e.g. Jackson, 2004). He suggested that Religious Education that was not reinforced by a Christian ethos in schools, and not taught by Christian teachers according to the authority of the Church broadly conceived (as it had been originally intended by the Education Act), was nonsense. Although Garforth was referring to a different cultural situation in the 1960s from that in present-day England, or other national contexts, I suggest that these observations are still relevant. This is because of the nature of Christianity and other religions - particularly the importance of community, communal practices, authority and role models to the processes of religious identity formation in adolescence.

Further education reform in 1988 (Education Reform Act) reinforced the compulsory status of Religious Education (retaining a little-used opt-out clause dating to 1870). The 1988 Act recognized the growing religious diversity of Britain and stated that Agreed Syllabuses must include the principal religions represented in Great Britain other than Christianity. This sanctioned multi-faith and Religious Studies models of Religious Education that had been included in the Birmingham Agreed Syllabus in 1975 and had been suggested by Ninian Smart, among others, prior to it (Smart, 1968). These developments can be considered the first 'instrumental turn', when Religious Education began to be conceived as a means to promote the understanding of 'other' religions rather than having the purpose of inculcating Christian culture and values as an end in itself. It was in this period that Religious Education became officially described as 'non-confessional', meaning that it should not be aimed at promoting faith: 'Syllabuses must not be designed to convert pupils, or to urge a particular religion or religious belief on pupils'

(DfE, 1994: 15).

Following the instrumental turn, several pedagogical models of Religious Education were suggested (Grimmitt, 2000). A key principle that has remained in use since this period is a formula differentiating between 'learning about' and 'learning from' religions originally suggested by Grimmitt (1987). This has been supposed by some to allow for nonconfessional education and personal reflection without impacting on the suitability of 
Religious Education for plural contexts - a dichotomy that is still widely used despite having various interpretations, some of which have been robustly critiqued (Fancourt, 2014; Teece, 2010).

A second instrumental turn in Religious Education took place in the first decade of the new millennium. Race riots in England in the summer of 2001 and the events of September 11th in the same year renewed interest in Religious Education on the assumption that it could promote much needed 'social cohesion' among different religions in a strained context (Grimmitt, 2010; Moulin, 2012). Religious Education's place in the curriculum was strengthened by the Labour Government with the introduction of The Nonstatutory Framework for Religious Education - centrally determined guidance to be used in the design of locally determined syllabuses, and by practitioners more generally (Moulin, 2012; QCA, 2004). The rationale for Religious Education given in the second instrumental turn rests upon concepts developed in previous decades, with an emphasis upon learning about 'different' beliefs, but doing so also in order to explore one's own position. A key influence in this guidance was the work of Andrew Wright, who suggests that religious literacy can be promoted by using critical realism as an 'under-labourer' to provide a conceptual base to explore religions (Wright, 2000, 2007). Religious Education should:

Challen[ge ... . pupils to reflect on, consider, analyse, interpret and evaluate issues of truth, belief, faith and ethics . . . enab[le ...] pupils to develop respect for and sensitivity to others, in particular those whose faiths and beliefs are different from their own. (QCA, 2004: 7)

The Coalition Government of 2010 led by David Cameron immediately reversed the Labour Government's policies regarding social cohesion, and although Religious Education continues to have the same legal status and much of the same official guidance, its status in schools has been reduced again by changes to the examination system, reduction of Government-funded teacher training schemes, and expansion of state-funded Academies free of local government control. However, the second instrumental turn had yielded unprecedented funding for research into Religious Education both in England and across Europe (Jackson, 2011; Moulin, 2012).

\section{Issues concerning lack of authority and religious education}

Garforth suggested that 'to teach Christianity without reference to the Church . . . is selfcontradictory', and recommended that Religious Education in public education should be connected to the life of local parishes, as he believed was intended by the 1944 Education Act (Garforth, 1961: 76). Despite the decline in Church attendance and Christian identification in England between 1961 and now, relevant aspects of this remark to my argument in this article are the importance of religious or theological authority and schoolbased religious practice to Religious Education. Without reference to a theological source of authority and taking part in religious practices such as prayer and communal worship, it could be argued that understanding Christianity in most of its forms becomes more abstract and, arguably, developing identification with it becomes more challenging. A similar issue has been raised in philosophy of education in the sense that there is a logical problem concerning the possibility of learning about a religion without adhering to it (Hand, 2006). However, there are important theological and sociological factors as well as 
epistemological ones to be considered here. Religions typically rely on notions of authority that ensure the continuation and legitimacy of their traditions, and processes of religious identity formation have been shown to be related to processes of identification and fidelity to groups, traditions, practices and authority, rather than assent to abstract propositions (Chaudhury and Miller, 2008; Moulin, 2014; Østberg, 2000). In the case of Christianity, concepts of authority are located within a tradition with greater or lesser emphasis upon, for example, conscience, Scripture, episcopal hierarchy, or apostolic succession - depending upon the various ecclesiological positions across and within denominations. Indeed, even defining or representing Christianity is problematic without reference to the authoritative positioning of a particular denomination or tradition (Astley, 1992).

Although Religious Education syllabuses are supposedly determined by local interdenominational and multi-faith committees with a legal bias towards the Established Church, they often make recommendations based on national trends in Religious Education practice and pedagogy. The instrumental turns in Religious Education have led to a profusion of recommended approaches that neither rest upon theological reasoning or religious authority nor include school-based religious practices (Grimmitt, 2000, 2010; Jackson, 2004). One assumption of nonconfessional Religious Education is that the truth claims of religions can be at odds with students' free exploration of beliefs, values and philosophies. This is perhaps most obvious when considering the vision of Religious Education advocated by Clive and Jane Erricker (Erricker and Erricker, 2000) which can be seen to represent some commonly held beliefs about appropriate contemporary Religious Education (Chater and Erricker, 2013). Erricker and Erricker argue that theologies marginalize learners in the classroom because they assert grand narratives that are not justifiably superior to students' own epistemological constructions. This is a good example of the conceptual weakness of some approaches to Religious Education, however. The position is problematic because it can only posit that philosophical positions are relative, including its own. This kind of paradox is noted in Plato's Theaetetus, which discusses the problematic relationship between educational theory and epistemological relativism (Plato, 1990).

The promotion of religious literacy using critical realism as an under-labourer may also result in conceptual problems owing to a lack of theological authority. This is because critical realism supposes that Religious Education can proceed through a process of critical, rational dialogue that brokers conflicting positions on religions based on the common pursuit of truth (Wright, 2007). However, religious and nonreligious stances often have incommensurable epistemological positions and appeal to sources of authority that cannot necessarily be shared (Moulin, 2009). It is unclear whether critical realism itself can allow for truth claims that are neither 'realistic' nor 'critical' such as mysticism or fundamentalism, for example. Critical realism can also be perceived (or easily misinterpreted by students and practitioners) as an ideology or set of absolute values in itself that may conflict with religious positions. It is not clear that such problems can be resolved without appeal to highly complex philosophical concepts, if at all (Moulin and Robson, 2012).

\section{Pathologizing pupil religion}

Religious literacy approaches tend to play down the impact social and cultural conditions may have upon a supposedly free and critical enquiry, whereas in reality such a debate can be distorted by competing ideological forces in society. For example, research suggests that 
'culture wars' over the role of religion in American public life may have little to do with a rational search for truth and more to do with the impact of the mass media (see Hunter, 1991; Louis and De Maio, 2008). Likewise, it has also been argued that minority ethnic and cultural groups can be stigmatized by political agendas that seek to make schools and society more equitable (Archer and Francis, 2006). Forms of education that aim to address prejudice and inequality, such as ignorance and prejudice about religions, could reinforce those differences rather than combatting them by creating a discourse of 'the other' in juxtaposition with the normal (Keddie and Niesche, 2012). This is because in creating a discourse of 'otherness', minority groups can be essentialized as static and inferior (Gore, 1992; Said, 2003). In the case of multifaith Religious Education specifically, it has been argued that religions, including Christianity and minority religions, are presented as outdated and dangerous (Copley, 2005). Religious Education can therefore lead to the 'pathologizing' of pupil religion (Ipgrave et al., 2010). An overview of research undertaken in the past decade, given below, confirms several problems with Religious Education in these respects.

Studies have found that students who identify with religions may be critical of Religious Education, particularly in the respect that it does not recognize the perspectives of minority religious groups, or represent religious traditions accurately or fairly (Head, 2009; Ipgrave, 1999; Jackson et al., 2010; Weller et al., 2001). These empirical studies resonate with the work of scholars who have also argued that Religious Education can present inaccurate or distorted accounts of religion, encourage its philosophical critique, or even that it constitutes confessional secular humanism (Barnes, 2009; Baumfield et al., 2012; Hayward, 2006; Lundie, 2010; Strhan, 2010; Thompson, 2004a, 2004b). Studies of Religious Education teachers' professional identities also show that they can be publicly hostile towards religion in lessons in order to make the subject more appealing to students of no religion (Sikes and Everington, 2004).

The teaching of Christianity has been considered a cause for concern in Religious Education in particular. Hayward (2006) analysed the content of 34 Locally Agreed Syllabuses to find that Christianity can be reified, simplified and often divorced from its theological foundations. The findings of The Biblos Project (Copley, 1998; Copley et al., 2001, 2004) suggest that the Bible is treated similarly: it can be stereotyped, simplified and secularized without demonstrating the diversity of its varied interpretations within and outside the Christian tradition. Instead, the Bible is presented as espousing ethical platitudes, without allowing for theological interpretations. In the famous stories of the Parable of the Good Samaritan or David and Goliath, for example, the texts' supposed meanings are often expressed, in the former, in terms of the importance of helping others, and, in the latter, the success of the underdog - rather than considering what such narratives may say about God.

Office for Standards in Education reports also stress that there are problems of simplification, stereotyping and insufficient representation of diversity within Christianity in secondary school lessons (Ofsted, 2007, 2010). Fancourt (2012) concludes a comprehensive review of empirical studies into the teaching of Christianity, with three principal findings: the way that Christianity is treated in classrooms cannot be separated from the way Christianity is treated in English society more generally (a hypothesis that resonates with the work of Copley, 2005); presenting Christianity clearly is not a common educational aim; and relatively little research has been completed in understanding how students may learn about Christianity, particularly the more difficult concepts. 
The representation of religions other than Christianity in Religious Education can also be inauthentic and inaccurate (Moulin, 2015; Revell, 2010, 2012). Ipgrave (1999) found that Muslim students reported different explanations for religious practices and beliefs than those incorporated in Religious Education lessons. She observed power struggles between teachers and students in lessons when teachers' knowledge seemed lacking in comparison with their students. Nesbitt (1998) also found that the content of curriculum materials and textbooks in Religious Education were perceived as inaccurate, generalized and stereotyped by Hindu and Sikh students. Students' concern about the inaccurate representation of their own traditions was also reported in an evaluation of materials used by schools to teach about religions (Jackson et al., 2010). Christian students reported that textbooks made their faith unappealing and outdated. Jewish students felt that the representation of Jews was based on Orthodox traditions that were not maintained by many Jews at home. In another study, Head (2009) found that Mormons' support for Religious Education and collective worship was weak and that when Mormonism was included in school-based Religious Education, it was perceived as inaccurately or negatively portrayed.

\section{The potential impact of Religious Education upon religious identity formation}

The instrumental turns in Religious Education have meant religious educators have not considered the subject in terms of its impact upon individuals' religious identity formation (Moulin, 2011). Only recently has research begun to be conducted in order to understand the potential impact of Religious Education upon religious identity construction (Moulin, 2014; Streib, 2001; Thanissaro, 2012; Visser-Vogel et al., 2012). Studies with secondary school students who identified with Christianity, Islam or Judaism have found that their perspectives of Religious Education could resonate with the criticisms in the literature given above and were sometimes reported to challenge their beliefs, identifications and affiliations (Moulin, 2015, forthcoming).

These studies also suggest that the 'safe space' for the exploration and evaluation of religious and non-religious beliefs and practices advocated by religious educationists (see Fancourt, 2009; Jackson, 2014) is difficult to create given existing interreligious tensions and widespread religious prejudices. For example, in two studies, Religious Education lessons were reported to challenge religiously identifying students by focusing on problems in the Philosophy of Religion over the proofs of God's existence, presenting stereotypes and caricatures of religions and religious practices, and even the ridiculing of religious positions by atheist or agnostic teachers (Moulin, 2011, forthcoming1). Some researchers have argued that religiously identifying adolescents can learn effective strategies to manage these problems through Religious Education (Fancourt, 2009; Miller and McKenna, 2011; Nesbitt, 2001; Østberg, 2000; Streib, 2001). However, part of this management can include the 'masking' (Faircloth, 2012) of religious identities in fear of bullying and ridicule (Moulin, 2014). For example, a Jewish participant reported her concern about an incident when a teacher had told her class that she was Jewish because of the possibility of antiSemitic abuse, threats and violence (Moulin, 2011: 322).

The longitudinal impact of Religious Education upon religious identity formation cannot be surmised from small-scale studies. However, the findings of several studies do lend some support to the view that Religious Education as it is currently conceived could have a secular bias (Copley, 1998, 2005; Copley et al., 2001; Copley et al., 2004; Moulin, 
2011). One striking element of Christians' reported experiences of secondary schools in particular is their concern with the 'attack' on their belief in Religious Education lessons and in schools more generally (Moulin, forthcoming).

The treatment of Christianity in Religious Education can be seen as a reflection of common attitudes towards it in English society (Copley, 2005; Fancourt, 2009). Although sociologists are in agreement that there has been a decline in Church attendance in England since the time of Garforth's article, there is a divergence of views about the nature and extent of this decline. This ranges from Bruce's (2002) Nietzschean 'God is Dead' hypothesis and Brown's (2001) 'Death of Christian Britain' thesis, to theories that suggest that religious practice may decline while belief and identification remain (Davie, 1994) or that religion remains as 'implicit' (Bailey, 1997) or 'vicarious' (Davie, 2000) religion. A comparison of the 2001 and 2011 census data shows that identification with Christianity declined 12 per cent, from 71.7 per cent of the population reporting themselves as Christian in 2001, to 59.3 per cent in 2011 (Office for National Statistics, 2012). During the same period, the proportion of the population reporting no religion increased from 14.8 per cent in 2001 to 25.1 per cent in 2011 (Office for National Statistics, 2012). Research also suggests that adolescents are less likely to practise Christianity than are adults (Park et al., 2004).

Copley (2005) speculated on the possible relationship between Religious Education and secularization. The limited available data surveyed in this article suggest that Religious Education could have a secularizing influence upon young people at an important time in their identity formation. The concept of identity masking, for example, posits that when entering schools, religious adolescents can give up, or hide, their beliefs and practices for fear of ridicule (Moulin, 2014). As Religious Education curricula can challenge religious interpretations of reality and prompt peers to ridicule religious beliefs, religiously adhering students may feel less able to publically acknowledge their faith, perhaps making it more likely that others will also mask their religious identities. For Christians who mask their identity, lives become divided between the private and religious, and the public and secular - an analysis congruent with most accounts of secularization (Brown, 2001; Bruce, 2002; Davie, 2000). This could potentially act as a positive feedback mechanism for the secularization of mentalities and practice, although this could not be proven without largescale longitudinal studies. Although it may be expected that non-religious schools should not support the religious formation their students, it would seem that Religious Education in Church-affiliated schools may be subject to similar problems (Moulin, forthcoming).

\section{Conclusion}

This article expresses doubts about Religious Education with regard to its impact upon religious identity formation and its lack of recourse to religious authority. Without the tradition of a specific religion or denomination, the aims, methods and theological basis of Religious Education may become fractured, open to poor practice, and lack a commonly identified purpose. I suggest that those in favour of English-style Religious Education in public education need to address how the subject may conceptually and practically accommodate students who actually adhere to, identify with, or practise, religions. This is particularly important in a context such as the United States of America, where some religious communities have been concerned about the inclusion of Religious Education in the curriculum as a breach of their constitutional rights. 
Historically, Religious Education in England was meant to include religious practice and promote a Christian ethos in schools - albeit of a compromise in character, but where a broad consensus and Christian culture existed. What remains today, however, ironically may be problematic to those who identify with a religion. Religions in Religious Education can be trivialized, can be exaggerated, or have their 'religiousness' reduced in order to bring them into the public sphere. The longitudinal impact of Religious Education of this kind upon religious identification and practice in the long term is not known, and more research is needed in this area.

I suggest what is needed in the contemporary context is a Religious Education that is more sophisticated in its approach to plurality and at the same time more faithful to religions. Public schools with no religious affiliation must allow for religious freedom and account for plurality, but this should not form an overarching set of values that either distort religions or marginalize students' religious identity formation. In Church schools, however, perhaps it would be more appropriate to reconsider the benefits that may be brought to Religious Education when being undertaken in communities of faith and under the supervision of a religious authority. In this respect, I do not mean to argue against the inclusion of religions other than Christianity in Religious Education. My proposal is rather that those religious traditions that are different from that of the authority tradition underwriting Church school Religious Education should be approached from within the perspective of that tradition (i.e. treatment of non-Christian religions may be best approached through Christian theologies of religions). In all kinds of schools, however, educators need to provide students with an authentic and genuine encounter with religion or religions. For, after all, what use is salt if it loses its saltiness (Matt 5:13)?

\section{References}

Archbishops' Council Education Division (2014) Making a difference: A review of Religious Education in Church of England schools. London: Archbishops' Council.

Archer L and Francis B (2006) Understanding Minority Ethnic Achievement. London: Routledge.

Astley J (1992) Will the real Christianity please stand up? British Journal of Religious Education 15(1): 4-12.

Bailey EI (1997) Implicit Religion in Contemporary Society. Kampen, the Netherlands: Kok Pharos Publishing House.

Barnes LP (2009) Religious Education: Taking Religious Difference Seriously. London: PESGB.

Baumfield VM, Conroy JC, Davis RA and Lundie DC (2012) The Delphi method: Gathering expert opinion in religious education. British Journal of Religious Education 34(1): 5-19.

Brown CG (2001) The Death of Christian Britain. London: Routledge.

Bruce S (2002) God is Dead: Secularization in the West. Oxford: Blackwell. 
Chater M and Erricker C (2013) Does Religious Education Have a Future? London:

Routledge.

Chaudhury SR and Miller L (2008) Religious identity formation among Bangladeshi American Muslim adolescents. Journal of Adolescent Research 23(4): 383-410.

Conroy JC, Lundie D, Davis RA, et al. (2013) Does Religious Education Work? A Multidimensional Investigation. London: Bloomsbury.

Copley T (1998) Echo of angels: The first report of the Biblos Project. School of Education, University of Exeter.

Copley T (2005) Indoctrination, Education and God. London: SPCK.

Copley T (2008) Teaching Religion; Sixty Years of Religious Education in England and Wales (2nd edn). Exeter: University of Exeter Press.

Copley T, Lane S, Savini H and Walshe K (2001) Where angels fear to tread: The second report of the Biblos Project. School of Education, University of Exeter.

Copley T, Freathy R, Lane S and Walshe K (2004) On the side of the angels: The third report of the Biblos Project. School of Education, University of Exeter.

Cruikshank M (1964) Church and State in English Education: 1870 to the Present-day. London: Macmillan.

Davie G (1994) Religion in Britain since 1945: Believing without Belonging. Oxford: Blackwell.

Davie G (2000) Religion in Modern Europe: A Memory Mutates. Oxford: Oxford University Press.

DfE (1994) Circular 1/94: Religious Education and Collective Worship. London: HMSO.

Erricker C and Erricker J (2000) Reconstructing Religious, Spiritual and Moral Education. London: RoutledgeFalmer.

Faircloth BS (2012) Wearing a mask vs. connecting identity with learning. Contemporary Educational Psychology 37(3): 186-194.

Fancourt N (2009) The safe forum: Difference, dialogue and conflict. In: Ipgrave J, Jackson R and O'Grady K (eds) Religious Education Research through a Community of Practice. Munster: Waxmann, pp. 201-215.

Fancourt N (2012) Teaching about Christianity in Religious Education: A review of research. Department of Education, Oxford University. 
Fancourt NPM (2014) Re-defining 'learning about religion' and 'learning from religion': A study of policy change. British Journal of Religious Education 37(2): 1-16.

Garforth FW (1961) Doubts about secondary school Scripture. Religion in Education 28(2): 73-76.

Gore J (1992) What can we do for you! What can 'we' do for 'you'? Struggling over empowerment in critical and feminist pedagogy. In: Luke C and Gore J (eds) Feminisms and Critical Pedagogy. London: Routledge.

Grimmitt M (1987) Religious Education and Human Development. Great Wakering: McCrimmons.

Grimmitt M (ed.) (2000) Pedagogies of Religious Education. Great Wakering: McCrimmons.

Grimmitt M (ed.) (2010) Religious Education and Social and Community Cohesion. Great Wakering: McCrimmon Publishing.

Groome T (2013) Teaching to 'learn from' religious traditions. REA Annual Meeting 2013: Coming Out Religiously - Religion, the Public Sphere, and Religious Identity Formation.

Hand M (2006) Is Religious Education Possible? A Philosophical Investigation. London: Continuum.

Hayward M (2006) Curriculum Christianity. British Journal of Religious Education 28: $153-171$.

Head JR (2009) The experience of Mormon children in English school-based religious education and collective worship. The International Journal of Mormon Studies 2: 197-207.

Hunter J (1991) Culture Wars: The Struggle to Define America. New York: Basic Books. Ipgrave J (1999) Issues in the delivery of religious education to Muslim pupils: Perspectives from the classroom. British Journal of Religious Education 21(3): 146-157.

Ipgrave J, Miller J and Hopkins P (2010) Responses of three Muslim majority primary schools in England to the Islamic faith of their pupils. International Journal of Migration and Integration 11(1): 73-89.

Jackson R (2004) Rethinking Religious Education and Plurality. Abingdon: RoutledgeFalmer.

Jackson R (2007) Some recent developments in religions and education. British Journal of Religious Education 29(3): 213-215.

Jackson R (2011) Religion, education, dialogue and conflict: Editorial introduction. British 
Journal of Religious Education 33(2): 105-109.

Jackson R (ed.) (2014) Signposts: Policy and practice for teaching about religious and nonreligious worldviews in intercultural education. Council of Europe, Strasbourg.

Jackson R, Ipgrave J, Hayward M, et al. (2010) Materials used to teach about world religions in schools in England. Department for Children, Schools and Families, London.

Keast J (ed.) (2007) Religious Diversity and Intercultural Education: A Reference Book for Schools. Strasbourg: Council of Europe Publishing.

Keddie A and Niesche R (2012) Productive engagements with student difference: Supporting equity through cultural recognition. British Educational Research Journal 38(2): 333-348.

Louis B and De Maio G (2008) A prejudice for the thinking classes: Media exposure, political sophistication and the anti-Christian fundamentalist. American Politics Research 36(2): 155-185.

Lundie D (2010) Does RE work? An analysis of the aims, practices and models of effectiveness of religious education in the UK. British Journal of Religious Education 32(2): 163-170.

Miller J and McKenna U (2011) Religion and religious education: Comparing and contrasting pupils' and teachers' views in an English school. British Journal of Religious Education 33(2): 173-187.

Moore D (2007) Overcoming Religious Illiteracy: A Cultural Studies Approach to the Study of Religion in Secondary Schools. New York: Palgrave Macmillan.

Moulin D (2009) A too religious education? A thought experiment for teachers and theorists. British Journal of Religious Education 31(2): 153-165.

Moulin D (2011) Giving voice to silent minority: The experiences of religious students in secondary school religious education lessons. British Journal of Religious Education 33(3): 313-326.

Moulin D (2012) Religious Education in England after 9/11. Religious Education 107(2): 158-173.

Moulin D (2014) Religious identity choices in English secondary schools. British Educational Research Journal. DOI: 10.1002/berj.3151.

Moulin D (2015) Reported schooling experiences of adolescent Jews attending non-Jewish secondary schools in England. Race, Ethnicity and Education.

Moulin D (forthcoming) Reported experiences of anti-Christian prejudice among 
Christian adolescents in England, Journal of Contemporary Religion

Moulin D and Robson J (2012) Doing God in a liberal democracy. Oxford Review of Education 38(5): 539-550.

Nesbitt E (1998) Bridging the gap between young people's experience of their religious tradition at home and school: The contribution of ethnographic research. British Journal of Religious Education 20(2): 102-114.

Nesbitt E (2001) What young Hindus believe: Some issues for the researcher and the RE teacher. In: Heimbrock HG, Scheilke CT and Schreiner P (eds) Towards Religious Competence: Diversity as a Challenge for Education in Europe. Mu“ nster: LIT Verlag, pp. 150-162.

Office for National Statistics (2012) Religion in England and Wales. London: Office for National Statistics. Ofsted (2007) Making Sense of Religion. London: Ofsted.

Ofsted (2010) Transforming Religious Education. London: Ofsted.

Østberg S (2000) Islamic nurture and identity management: The lifeworld of Pakistani children in Norway. British Journal of Religious Education 22(2): 91-103.

Park A, Philips M and Johnson M (2004) Young People in Britain: The Attitudes and Experiences of 12-19 Year Olds. London: DfES.

Plato (1990) The Theatetus. Indianapolis: Hackett.

QCA (2004) Non-Statutory National Framework for Religious Education. London: QCA.

Revell L (2010) Religious education, conflict and diversity: An exploration of young children's perceptions of Islam. Educational Studies 36(2): 207-215.

Revell L (2012) Islam and Education: The Misrepresentation of a Religion. Stoke: Trentham Books.

Said E (2003) Orientalism. Reprint with new preface edition. London: Penguin.

Sikes P and Everington J (2004) RE teachers do get drunk you know: Becoming a religious education teacher in the twenty-first century. Teachers and Teaching: Theory and Practice 10(1): 21-33.

Smart N (1968) Secular Education and the Logic of Religion. London: Faber and Faber.

Streib H (2001) Inter-religious negotiations: Case studies on students' perception of and dealing with religious diversity. In: Heimbrock HG, Scheilke CT and Schreiner P (eds)

Towards Religious Competence: Diversity as a Challenge for Education in Europe. Munster: LIT Verlag, pp. 129-149. 
Strhan A (2010) A religious education otherwise? An examination and proposed interruption of current British practice. Journal of Philosophy of Education 44(1): 23-44.

Teece G (2010) Is it learning about and from religions, religion or religious education? And is it any wonder some teachers don't get it? British Journal of Religious Education 32(2): 93-103.

Thanissaro PN (2012) Measuring attitude towards RE: Factoring pupil experience and home faith background into assessment. British Journal of Religious Education 34(2): 195-212.

Thompson P (2004a) Whatever Happened to Religious Education? Cambridge: The Lutterworth Press.

Thompson P (2004b) Whose confession? Which tradition? British Journal of Religious Education 26(1): 61-67.

Visser-Vogel E, Westerink J, de Kock J, Barnard M and Bakker C (2012) Developing a framework for research on religious identity development of highly committed adolescents. Religious Education 107(2): 108-121.

Weller P, Feldman P and Purdam K (2001) Religious Discrimination in England and Wales. London: Home Office.

White J (2004) Should religious education be a compulsory subject? British Journal of Religious Education 26(2): 151-164.

Wright A (2000) The spiritual education project: Cultivating spiritual and religious literacy through a critical pedagogy of religious education. In: Grimmitt M (ed.) Pedagogies of Religious Education. Greater Wakering: McCrimmons, pp. 170-188.

Wright A (2007) Critical Religious Education, Multiculturalism and the Pursuit of Truth. Cardiff: University of Wales Press. 